\title{
Kirstenbosch: A unique blend of beauty and science
}

\section{BOOK TITLE:}

Kirstenbosch: The most

beautiful garden in Africa

\section{AUTHOR:}

Brian J. Huntley

ISBN:

978-1-43170-117-9

\section{PUBLISHER:}

Random House Struik,

Cape Town, R300

\section{PUBLISHED:}

2012

\section{REVIEW TITLE:}

Kirstenbosch: $A$ unique blend of beauty and science

\section{REVIEWER:}

Brian W. van Wilgen

EMAIL:

BvWilgen@csir.co.za

\section{AFFILIATION:}

CSIR Natural Resources and the Environment, Stellenbosch, South Africa

\section{POSTAL ADDRESS:}

CSIR Natural Resources and the Environment, PO Box 320 , Stellenbosch 7599, South Africa

\section{HOW TO CITE:}

Van Wilgen BW. Kirstenbosch: A unique blend of beauty and science. S Afr J Sci. 2013;109(5/6), Art. \#a0013, 1 page. http://dx.doi.org/10.1590/ sajs.2013/a0013

(C) 2013. The Authors. Published under a Creative Commons Attribution Licence.
The Kirstenbosch National Botanical Gardens, regarded by many as one of the top 10 botanical gardens in the world, celebrates its centenary in May 2013. The garden is distinctive in that it was the first in the world to be established to preserve a country's unique flora, and in no small part owes its existence to Harold Pearson, a Cambridge graduate and erstwhile Professor of Botany at the South African College. Pearson's vision for the role of a botanical garden was presented in an address to the South African Association for the Advancement of Science in 1910. He foresaw an institution that could take advantage of the country's immense floristic wealth by focusing on research, indigenous plant horticulture, economic botany and plant conservation. Pearson's choice of the Kirstenbosch site was made in February 1911, when he was recorded to have exclaimed 'this is the place!' on being shown the magnificent potential location by Neville Pillans. This book provides a history of the establishment of the Kirstenbosch garden from this point in 1911 on, and outlines the many achievements, setbacks and triumphs of those who worked there.

Following Pearson's death in 1916, the duties of Director were taken over by Robert Compton, who served in this capacity for 34 years, and then by Brian Rycroft whose tenure spanned a further 30 years, ending in 1983. During this long period, the research budget of the National Botanical Garden (NBG) was limited, especially when compared with the better-funded Botanical Research Institute (BRI) based in Pretoria. The NBG's research was focused on the establishment of a herbarium (now the Compton Herbarium), the collection of plant specimens and taxonomic research. Rycroft was replaced by Kobus Eloff as Director in 1983, during which time the NBG and BRI were merged into a single organisation - the National Botanical Institute (NBI). In the book, Huntley describes this event as 'the most dramatic change in the history of the country's institutional arrangements for botany', and new life was henceforth breathed into the botanical research agenda. Somewhat against expectations, a decision was made to locate the head office of the amalgamated NBI at Kirstenbosch, and not Pretoria.

South Africa's emergence as a democratic country in 1994 brought new opportunities and an increased flow of funding. Brian Huntley, who took over as Director in 1990, was tasked with addressing the financial sustainability of the botanical gardens, which for almost eight decades had been plagued by financial woes. Today, the diversification and growth of funding sources has placed the gardens on a positive financial trajectory, drawing substantial income from entrance fees, open-air concerts, restaurants, shops, conference facilities, and plant and art sales. The NBI also became a preferred partner to head up foreign-funded investments into conservation, eventually administering over R150 million in donor funds for projects to promote conservation in the Fynbos and Succulent Karoo Biomes, and to counter the threat posed by invasive alien species.

South Africa's democratic government ratified the international Convention on Biodiversity, followed in 2004 by the promulgation of the National Environmental Management: Biodiversity Act (NEMBA). NEMBA broadened the mandate of the NBI beyond the study of plants, and established the South African National Biodiversity Institute (SANBI). Although SANBl's head office was relocated to Pretoria, it retained a strong presence at Kirstenbosch, with significantly expanded research facilities. Examples of SANBI's recent achievements include the monumental works on the vegetation of South Africa, Lesotho and Swaziland ${ }^{1}$ (describing 435 vegetation types mapped at a scale of 1:1 million), and the Red List of South African Plants ${ }^{2}$ (assessing 20456 plant species). These products, arguably the most comprehensive regional treatments of the topics anywhere in the world, were led from Kirstenbosch and involved 96 and 169 collaborating authors, respectively.

By its own admission, this book is 'a celebration of Kirstenbosch rather than a scientific text', and yet it contains much that will fascinate those with interests in botany, ecology, conservation and the future of our unique and diverse ecosystems. The text covers the history of early botanical exploration and discovery, the unique nature of South Africa's vegetation, the importance of ex-situ conservation, the role of Kirstenbosch as an educational resource, the expansion of the garden network to include nine additional NBGs across the country, and new research directions to address the modern challenges of climate change, desertification and biodiversity conservation. Brian Huntley's outstanding text is based on over four decades of experience as an ecological research administrator, and it covers a remarkable breadth of issues. The superb illustrations include modern photographs (principally by Adam Harrower), artwork, and a host of fascinating historical photographs. This book is likely to find wide appeal among scientists as well as general readers.

\section{References}

1. Mucina L, Rutherford M. Vegetation map of South Africa, Lesotho and Swaziland. Pretoria: South African National Biodiversity Institute; 2004.

2. Raimondo D, Von Staden L, Foden W, Victor JE, Helme NA, Turner RC, et al. Red list of South African plants. Strelitzia 25. Pretoria: South African National Biodiversity Institute; 2009. 